\title{
From Alcoholism to Firm Abstinence: Revealing multidimensional Experiences of Treated Alcoholics in Croatia
}

\author{
Ana Opačić ${ }^{1}$, Vendi Keserica ${ }^{1}$ \\ ${ }^{1}$ Department for Social Work, Faculty of Law, University in Zagreb, Zagreb, Croatia
}

\begin{abstract}
Alcoholism is significant public health problem in Croatia and affects almost a quarter of population. However, there has been a lack of qualitative research revealing complexity of phenomenon and experiences related to alcoholism, treatment and abstinence. Paper reports on conducted phenomenological qualitative study with 9 participants that have undergone phases from addiction to established abstinence. It is noted that these experiences are non-linear, personal trajectories are different, and above all they are multidimensional. Experiences are multidimensional and constructed on 6 levels: cognitive, emotional, behavioral aspects, relations with social context, important life events and alcoholism and treatment in narrow clinical sense. In stage when alcoholism is developing, attempts of balancing and experiments with sobriety exist, and participants assign different meanings to drinking. In stage of crucial change that mostly happens within hospital treatment, treatment itself is generator of many specific challenges with many experiences of emotional, cognitive or behavioural crisis during abstinence. In stage of maintaining abstinence, participants differ in a way that some have narrower approach focusing on abstinence as behavioural task; while other have more holistic approach viewing alcoholism just as an inducement for overall transformation. Experiences related to alcoholism and treatment are multidimensional and more introspective. Phenomenological study enables us to get intimate personal stories that have strong legitimacy in further understanding of the phenomenon.
\end{abstract}

Key words: alcoholism, phenomenological analysis, qualitative study

Copyright (C) 2019 KBCSM, Zagreb

e-mail: alcoholism.kbcsm@gmail.com•www.http://apr.kbcsm.hr

\section{Introduction}

Alcoholism is significant public health problem. There are app. 250000 registered alcoholics in Croatia [1]. Over 13000 new

Correspondence to: Ana Opačić, PhD, assistant professor, Department for Social Work, Faculty of Law, University in Zagreb, Zagreb, Croatia, Address: Nazorova 51, Zagreb, Croatia E-mail: ana.opacic@pravo.hr, Phone: 0038514895 801, Fax: 0038514821206 patients are registered in primary health care every year [2]. Considering family members, it can be assumed that alcoholism affects around quarter of total Croatian population. Since alcoholism is defined as mental illness [3], psychiatric system has most of the authority of its treatment. However, alcoholism includes a variety of psychosocial aspects and many forms of psychosocial support [4]. 
Quantitative researches are dominant in this area, mainly focused on etiology and treatment [5]. However, qualitative methodology in addiction research can contribute to discovering deeper meanings attributed to a phenomenon, the processes under which participants go and insights that arise from specific social context [6]. Understanding direct personal experiences is kind of bottomup approach through which new perspectives on existing knowledge or new ideas can arise.

Available qualitative studies are focused on deepening and extending knowledge on dimensions that haven't been sufficiently elaborated, whether particular phenomenon (e.g. co morbidity of alcoholism and depression, self-concept, benefits out of drinking), rare forms (e.g., alcoholism of women) or deepening some parts of experiences, such as the development of alcoholism, treatment or abstinence. Female participants are often in these studies. Some qualitative studies showed that women attach different meanings to drinking: as way of undertaking "male behavior", self-confirming and detachment from everyday life [7]. Also, in other study, alcoholism was linked to four themes: power and pleasure, constant balance between release and retention of control, loss of control, feature of life style and self-presentation [8]. Shinebourne and Smith presented story of one participant for whom drinking was experienced as instability, helplessness and insecurity, but it also had meaning of liberation of creativity, energizing and excitement [9]. From the female point, alcoholism is linked with depression in a way that alcohol is seen as medicine that helps regulating internal world and suppresses emotional burdens [10]. Orford and associates found that participants recognize drinking as help in dealing with life's circumstances, enhancing self- confidence, relaxing and feeling carefree [11]. Reported adverse consequences are physical consequences, loss of control, interference in carrying out other responsibilities and disruption of relations with surrounding.

Some other researchers were focused on the experience of treatment. Ekendahl investigated the experience of coercive treatment [12]. Negative aspects of these experiences are sense of imprisonment, coercion, lack of different rehabilitation facilities, focus on discharging and development of resistance toward government agencies as being controlling. On other side, treatment is seen as an opportunity to stay sober and the idea of social control over drinking is supported. In residential rehabilitation, participants found therapist's approach, attitudes towards rehabilitation and practical help to be helpful [13]. Rehabilitation institution is perceived as safe place, participants had a sense of belonging and getting support through group work, got specific knowledge about the addiction and adopted techniques of coping with stress.

The last group of qualitative studies on alcoholism has examined the experience with alcohol as a progressive process from its inception to the treatment and the establishment of abstinence. Mohatt and associates recognized 5 processes [14]. Three are found in dealing with alcoholism: thinking about the termination of drinking, experimenting with sober stages and reaching the turning point where decision is made. Other two are connected with abstinence: active coping with alcoholism and exercising satisfying lifestyle. Yeh, Che and Wu named this stages: indulgence in which there is no control over consumption followed by physical and psychical damage; ambivalence where there is both desire to quit and continue drinking with the occurrence of fear from living without alcohol; and 
attempt, where decision on sobriety is tend to be preserved [15]. Belief in personal abilities, possibility of change, sense of self-rescuing and exchange of social support were seen as crucial ideas. Similarly, Bowden represents this process as a journey: from departure that involves negotiating with oneself toward initiation which marks bridging the gap between drinking and sober life [5]. Possible risks are seen in accumulated negative emotional states, such as fear and depressed mood. Brown and Stewart also noted that depressed symptoms remained after the treatment and where pharmacotherapy and group support was helpful [16]. The third phase by Bowden is a stage of recurrence where person faces personal changes and life's responsibilities in a different way [5]. It can be concluded that experiences of alcoholism are multi-layered, sometimes ambivalent, and it's necessary to deepen them.

Due to lack of qualitative approach in the field, the aim of this phenomenological study was to gain insight into the experiences of the development of alcoholism, treatment and maintaining abstinence.

\section{Subjects and methods}

This research is phenomenological study mainly oriented on person's experiences. Data were collected through unstructured interviews where participants told their story from the period of alcoholism, making decisions about treatment, treatment, abstinence and concluding with some insights about alcoholism. Two researchers were involved in conducting interviews. Interviews were conducted with 9 participants recruited from clubs of treated alcoholics. After first contact with therapists, researchers made contact with participants in writing and orally explaining purpose of the research, method and principle of confidentiality. After oral consent has been gained, agreement on date and place where interviews will be held was made.

There were 2 women and 7 men, age from 46-73 years in the sample. 8 participants are married and have children. All participants have experience of abstinence: two longer than 15 years, two longer than 5 years, two longer than 2 years and three less than a year. Two of them established abstinence without hospital treatment. Three participants have experience of ending abstinence sometimes in their past, but have established it again.

Data were analysed using interpretative phenomenological analysis through following steps [17]: 1) Notes were made during conducting the interview. After writing transcript, comments and preliminary summary interpretation were made; 2) after first reading, each transcript was read in detail to identify themes; 3) Similar themes are grouped together and ordered as superior and subordinate; 4) Common themes among cases are detected.

For validating conclusions, researchers' self-reflection was made during and after the implementation of each interview in order to critically examine conclusions in the light of subjective ideas [18]. Also, one researcher worked phenomenological analysis, while the other independently recorded their interpretations that are consulted during the presentation of final conclusions.

\section{Results}

Experiences through stages of alcoholism, change and abstinence are not always happening in a progressive straight-line course, as some earlier studies indicate. These experi- 
ences are multidimensional consisted of cognitive processes, emotional experience, relationship with social environment, significant events, and characteristics of alcoholism and its treatment in narrow clinical sense. Ambivalences were found among different experiences and even within a single one. Participants differ in each of crucial three stages:

Diversity of experience in the development of alcoholism. For all male participants, alcoholism is progressively developed and unconsciously integrated into life aspects. Four of them express psychical and physical dependence. Three participants indicate "overwhelming" addiction characterized by loss of control over drinking, but also over behavior and functioning in general that comes to a point of culmination. These points were committing a crime, threat of suicide and common theft in order to reach the alcohol. Two female participants see development of alcoholism as an excess phase in life with function in something other than drinking, as a way to facilitate everyday functioning or some kind of support in depressed moods.

Differences among experiences of change. For most participants, change was imposed from outside, while three participants see it as their own choice. Participants who initiated termination of drinking and treatment were aware of alcoholism before, either through early form of hospital treatment, or through their own insights about behaviour change. For the remaining participants, key factor for change was consciousness of alcoholism developed through informing what alcoholism is, and connecting it with their own experience.

Diversity of experiences of maintaining abstinence. Most participants demonstrate their decision for abstinence as final and inevitable. It could be noted as linear progressive abstinence. 3 participants ( 2 women and 1 man) made decision to abstain. However, they indicate that this process is conditioned by other factors, such as support from environment, dealing with emotional difficulties and reducing environmental pressure on drinking. 2 of them are currently hospitalized, and one participant has experience of establishing multiyear abstinence, but with periodic short-term recurrences.

Multidimensional experiences of alcoholism, treatment and abstinence

It is found that experiences trajectories of our participants are composed of 6 dimensions: thoughts, emotional states, events, relationships with other people, behaviors and experiences of dealing with alcoholism in the narrow clinical sense. A brief overview of common themes regarding these dimensions through phases of addiction, period of change and abstaining is given in Table 1. and will be elaborated in the following text.

Development of alcoholism and treatment in the narrow sense

First dimension encompassed themes referring to usual notion of alcoholism as mental illness treated in medical settings. Development of alcoholism is seen through usual progressive course that follows clinical symptoms. Most participants consumed alcohol from an early age, drinking became part of everyday life, amount of alcohol increased over time:

I do not know how one can describe it. I do not know, maybe, in my view, from high school, maybe even before that. First as a curiosity, you figure it out what booze is. Then in high school, at birthdays, celebrations, parties. Then I went into the army. Well, maybe in the army was not so much, but when we got free, then it was like we had to make it up. Then later, when we returned from the army 
Table 1. Common themes to the different dimensions in the development stages and treatment of alcoholism

\begin{tabular}{|c|c|c|c|}
\hline & $\begin{array}{l}\text { Development of Alco- } \\
\text { holism }\end{array}$ & Treatment & Abstinence \\
\hline $\begin{array}{l}\text { Alcoholism } \\
\text { in narrow } \\
\text { sense }\end{array}$ & $\begin{array}{l}\text { - progressive course } \\
\text { - supportive social con- } \\
\text { text } \\
\text { - self-initiated rejection } \\
\text { of alcohol }\end{array}$ & $\begin{array}{l}\text { - negative aspects of } \\
\text { hospital treatment } \\
\text { - benefits from hospital } \\
\text { treatment }\end{array}$ & $\begin{array}{l}\text { - maintenance of absti- } \\
\text { nence } \\
\text { - activation in the clubs } \\
\text { for treated alcoholics }\end{array}$ \\
\hline $\begin{array}{l}\text { Important } \\
\text { life events }\end{array}$ & $\begin{array}{l}\text { - regular events } \\
\text { - adverse external cir- } \\
\text { cumstances } \\
\text { - adverse personal events }\end{array}$ & - & $\begin{array}{l}\text { - significant family } \\
\text { changes }\end{array}$ \\
\hline $\begin{array}{l}\text { Cognitive } \\
\text { aspects }\end{array}$ & $\begin{array}{l}\text { - unawareness of alco- } \\
\text { holism } \\
\text { - assigning meaning to } \\
\text { drinking } \\
\text { - critical awareness to- } \\
\text { ward drinking }\end{array}$ & $\begin{array}{l}\text { - understanding of alco- } \\
\text { holism } \\
\text { - cognitive reduction of } \\
\text { alcoholism extent } \\
\text { - general self-reflection }\end{array}$ & $\begin{array}{l}\text { - critical understanding } \\
\text { of alcoholism } \\
\text { - categorical abstinence } \\
\text { - } \text { self- reflection }\end{array}$ \\
\hline $\begin{array}{l}\text { Emotional } \\
\text { aspects }\end{array}$ & $\begin{array}{l}\text { - negative emotional ex- } \\
\text { perience } \\
\text { - positive emotional ex- } \\
\text { perience }\end{array}$ & $\begin{array}{l}\text { - emotional quakes } \\
\text { - emotional stimuli }\end{array}$ & $\begin{array}{l}\text { - emotionally aggravating } \\
\text { experiences } \\
\text { - mitigating emotional } \\
\text { states }\end{array}$ \\
\hline $\begin{array}{l}\text { Relations } \\
\text { with social } \\
\text { environment }\end{array}$ & $\begin{array}{l}\text { - dysfunctional social } \\
\text { relations } \\
\text { - supportive relations } \\
\text { - others' submissive rela- } \\
\text { tion toward alcoholism } \\
\text { - others' proactive rela- } \\
\text { tion toward alcoholism }\end{array}$ & $\begin{array}{l}\text { - treatment as risk for } \\
\text { social relations } \\
\text { - unsupportive social en- } \\
\text { vironment } \\
\text { - implications of treat- } \\
\text { ment on improved } \\
\text { quality relations }\end{array}$ & $\begin{array}{l}\text { - supportive relationships } \\
\text { - aggravating relations } \\
\text { - improvement of quality } \\
\text { of social relations }\end{array}$ \\
\hline $\begin{array}{l}\text { Behavioral } \\
\text { aspects }\end{array}$ & $\begin{array}{l}\text { - passiveness in life func- } \\
\text { tioning } \\
\text { - anti-social behavior } \\
\text { - prosocial behavior }\end{array}$ & $\begin{array}{l}\text { - coherence of decisions } \\
\text { and behavior }\end{array}$ & $\begin{array}{l}\text { - life without alcohol } \\
\text { - detabuisation of alco- } \\
\text { hol } \\
\text { - behavioral changes }\end{array}$ \\
\hline
\end{tabular}

to work and how it usually goes, first-pays. So you see every day, guys who work with you, let's go to coffee, and with coffee something to drink. ... So it continued at work-birthdays, name days. And that, you would say, become common over time (R1).

Some participants reported that they recognized signs of mental and physical depen- 
dence. Also, one participant reported on adjusting behaviour to get alcohol easily.

Another important issue is socially supportive context for drinking. It includes supportive family circumstances for drinking, such as alcoholism in the family, availability of alcohol, and even the use of alcohol in early childrearing as a way of appeasing them:

And my alcoholism began at an early age. I started drinking when I was born at the beginning of the war in 40's. We were poor, and it was war.... And then, to make peace at home, instead of milk, we got crumbled bread in wine. This was to be still all night, fall asleep and not to yell. And that was the beginning. Later, in the $4^{\text {th }}$ or $5^{\text {th }}$ grade, I drank a lot.

From the beginning (R2).

Alcohol was also available and consumed in other forms of social life, such as work place, military, during leisure and while socializing with friends.

Progressive development of alcoholism is in some way broken by the insight that participants have self-initiated experience of rejection of alcohol, which includes even few years of abstinence, setting their own limits in drinking, drinking only in solitude and developing strategies for coping with adverse consequences (abstinence after a period of intense drinking) or their prevention (e.g., refusal to drink in high-risk activities at work).

Since medical institutions are predominantly engaged in dealing with alcoholism in Croatia, change is often equated with the hospital treatment. Seven participants have gone through the usual hospital treatment, while two didn't. Based on experience with treatment, statements are grouped into negative aspects of hospital treatment and benefits. Negative aspects are: impersonal approach of staff, predominance of pharmacotherapy, unfilled time, lack of hospital control and disorientation in the system:

I was there for two and a half months, as I needed to stay for three, but psychically I couldn't hold on.... I listened to other people's experiences, stories, and everything. I had absolutely no contact with my doctor, she came to check me sometime in the beginning, second day, and that's it. Once I asked her how long I'll be there, and she told me „Well, as long as necessary.” You see, a therapeutic conversation or any conversation whatsoever with her - nothing (R1).

Positive aspects of hospital treatments are: plenty of activities, learning new things about alcoholism, sense that hospital is a secure environment and establishing regular daily rhythm:

So, I get up in the morning, first perform bygiene activities, and after work in small groups. People slightly open here, someone opens a little more, someone less. I like that; everyone has their own life stories. ... I like to listen to others' experiences. After, there is great therapeutic community where the doctor is. He is inevitable at this therapy and I like that. Definitely, whoever wants to listen can learn a lot from it (R3).

After treatment, 6 out of 9 participants talk about the experience of maintaining abstinence for more than a year. Only two of them report on experience of withdrawal symptoms.

Now it comes the time when it gets critical for the relapse in December, when I remember how different was at home back then. Relatives, friends, cousins, we all bung out, it was Christmas, New Year... then it's stressful to me. .... Although I'm not alone, but still, I do not know why, attacks me in the 11 months and I start to drink. Antabuse. ... Recurrences are in my case luckily always very short (R4). 
All these six participants noted activation in clubs of alcoholics in treatment through participation on regular meetings, getting a formal position and valuing the club as a fuse for maintenance of abstinence.

At the club, if you are honest about what's troubling you, you shouldn't lie, hide anything, no matter what the problems are, marital and others. And when we talked in the club about matters that concern us, these things were resolved, and didn't repeat anymore (R2).

\section{Important life events}

Participants cited important life events that have marked their experiences only in the stage of development of alcoholism. In addition to regular events (education, employment, conceiving a family), participants cited as significant adverse external circumstances: death of a family member, war, changes of residence and loss of job. In addition to external, participants noted adverse personal events, such as personal health problems, problems in education, the threat of suicide, co morbidity with PTSD, committing a crime with imprisonment. In other phases, there is almost no mention of any significant life events.

Cognitive aspects of the experience of alcoholism

During the development of alcoholism, in cognitive reasoning three substantially different themes were recognized. Two of them encourage development of alcoholism: unawareness of alcoholism and assigning meaning to drinking. Unawareness of alcoholism is manifested through the denial of severe drinking or lack of awareness of addiction.

And there was this fellow who works with us and we teased him. And the first time I saw the Antabuse. He drunk Antabuse with alcohol and nearly drowned, almost died. ... And I've seen it all, but I thought I'm not that one. It is always this error. I have some time. I knew that mother died of cirrhosis of the liver, but It didn't come to my senses. I never thought this is it (R2).

Some participants assign meanings to drinking as a source of pleasure, escape from reality, a source of energy, a way of calming and encouragement to communicate with others.

I worked from 6 am to 3 pm, came home, became terribly depressed....husband opened a mechanic service. Practically, he wasn't entire day at home. When I came home had to raise kids, do their homework, didn't know what to do first - homework with them, dinner, food, ironing, cleaning... so it killed me. I had no one to belp me, ... so I was alone. It started to pull me to have a glass, to get calm, work faster, easier, and it was only that. And so little by little it lasted for three years (R4);

And then it became a babit to stop talking. I lost friends, as they didn't want to disturb me since they thought I had many obligations... But maybe I needed to tell someone, to sit down and cry. I had no one to share it with. And then one evening I summarized it all, husband at the hospital, son also, daughter must keep her pregnancy, little granddaughter, borrowed money to buy a car because we needed a car.... I reached for a glass. And got drunk just like that (R3).

As a counterpart to these, several participants develop a critical awareness of drinking in sense of becoming aware of progressive problematic drinking, notice changes in behaviour due to drinking or are generally familiar with alcoholism and have positive attitude about treatment.

Then I caught myself that I started buying wine. It was gone from home stocks, and 
I went to the store and bought wine, bread, and then I saw that it's becoming serious. And I just told my guys, I'm not the type of person who is silent, but two years ago I do not know if I spoke ten sentences. (R3);

So the time passed by and I haven't noticed that I drink more and more until I was so drunk to begin to think soberly: Man, you drunk 5 litters from 9 am till after lunchtime (R6).

During phase of changing, participants were partly focused on understanding of alcobolism. Following sub-themes are: understanding what alcoholism is, connecting learned with personal example and raising awareness of themselves as alcoholics, self-presenting as an alcoholic and making final decision on abstinence.

However, some participants cognitively reduce the extent of alcoholism by comparing with other "heavier" examples, or partly seeking in the treatment a way to return to the social consumption of alcohol.

Ob, I thought I could drink. And yet, I have not thought about the consequences. The man is in hospital but doesn't think how to stop drinking, but how to start to drink again. Check out this scheme. I was thinking, everyone speaks about ruin of families and ruin at work, and I listened to it. Finally, at the end, joke or not, we thought that we will not drink coloured drinks.... Colour is one that damages organism (2).

Some participants were demonstrating wider and more general self-reflection, which is expressed through the observation of personal changes and assigning meaning to treatment as new life beginning.

Well, awakening or the urge to make a decision is linked with the priority list. And it's obvious that the loss of freedom, compared to myself touched top of my priority list. So, this is the moment where the man startled and start thinking. Approach and communication with the therapist, conversation not only in club but also out of working hours, has in fact led me to become aware of it (R5).

In stage of established abstinence, there are three themes in cognitive aspects. Further critical understanding of alcoholism includes coping with the consequences of alcoholism, knowledge of what alcoholism is, taking personal responsibility for its development and rejection of old patterns of behaviour.

How did I feel? I felt then that I must go on. $I$ realized than, and realizing it now, that I can't afford a relapse, none. Because it would be the first and last. Sometimes when I get outside and walk a dog, look all places where I knew to bide the bottle... There at this neighbour, by this fence... Then you rewind movie back, at first it bothered me when the wine was sour, and later I didn't care, as long as it was alcobol (R1).

In accordance with previous is issue of categorical abstinence, which includes decision about sobriety and a significant shift away from alcohol in general.

Ob I never... a man comes into temptation. But I am a man who cuts once, and cuts. So for me there isn't or - but. I am or am not.... So, there wasn't question if I would relapse or not. Definitely not... So, I can't say that there was ascending phase of treatment... simple, there was cut (R5).

I think that it was that my friends filtered and I said that I'm treated alcoholic everywhere, no matter where, in the middle of supermarket where there were tastings of drinks. I'm not embarrassed to say. ... I haven't had any problems or crisis or anything. I've had this in mind, strong will, and promised to children, wife and myself (R6). 
At this stage more prominent issue is general reflection of oneself as a cognitive shift from the understanding of alcoholism. This includes constant self-reflecting, recognition of changes, insight into the same approach to life and orientation toward future.

I think I have learned in these 19 years, most importantly, that I cannot lie to myself. And when a man is honest to bimself, then it may resonate differently. It is one thing and another one is that I was nervous before. Everything bothered me if it wasn't exactly as I wanted... A lot has changed for the better. But it doesn't go overnight (R7).

\section{Emotional experience}

Based on statements in all three phases of experience with the development and treatment, there is certain "emotional ambivalence". In the initial stage of alcoholism, negative emotional experiences are experiences of grieving, depressed mood, sense of humiliation, fear of criticism, disappointment and existential uncertainty. Less frequently, participants cited positive emotional experiences, such as happiness for their own success and experience of good cheer and confidence in the stages of intoxication.

In the phase of change, participants talk about emotional quakes and emotional stimuli. Emotional quakes are found in experiences of shock, guilt, fear, loneliness, shame, and depressed mood.

And they brought me to the hospital and there was a nurse, and so I've heard, I didn't know, sobriety-room. She told me: "Sit here in this hall"; door was opened, on left was chair and doctor turned his back, and there was room with beds, all kinds of beds and everyone were tied. Jesus, when I saw it ... it helped me to see how it is... I think I was within 10 minutes sober. ... When I saw the hall, doors and beds, where they tied him and he's yelling, Jesus, I think, do I need to see myself like this- no, you won't (R7).

Emotional stimuli are found in the desire for healing, experiences of optimism, relaxation, courage, safety and life prospects.

I was in hospital thinking that I wasn't useful anymore, worthless. But miraculously surprise happened and one day nurse asked me if I could go to pick up bank accounts. "I can", I said. ... And I was going home cheerful as a bird. I said to my wife that I'll never drink again because I still worth something (R2).

For participants who achieve success in a multi-year abstinence, emotional ambivalence is still present. Emotionally aggravating are senses of past losses during alcoholism, shame, fear of sobriety and depressed mood.

Mitigating emotional states are visible in the return of self-esteem, developed desire for further progress, personal satisfaction with the progress and reconciliation with oneself.

You must begin to live purely. Truths are hard and painful, but tell them as soon as possible to get rid of this. If you keep inside some things you just torture yourself. Yourself and those around you. Because everyone saw me on the road and workplace, and prayed to God to stop drinking, but I wouldn't. And when I stopped, you have to say you're sorry. I was really a fool ( $\mathrm{R} 2)$.

\section{Relations with social environment}

In terms of relationships, through all three phases participants reported on bipolarity in relationship with environment. From participants' statements is seen that mostly they elaborate relations in family environment. In the stage of alcoholism development, more 
dysfunctional relationships within family and wider environment are indicated: whether it's about taking too much responsibility in the family, aloofness among members, violence, marital infidelity and lack of support from extended family.

Conflicts or aloofness appeared also within friendships. When it comes to the alcoholism, environment shows a dual position. The broader environment supports drinking either through non-reacting to drinking or even encouraging it.

They always offered me alcohol; I think that no one bothered I drunk so much. They told me that notbing will bappen, and to drink one, two, five glasses. They always supported me in my drinking, and when they heard about treatment, didn't approved it and told me I was insane (R8).

Some participants talk about more proactive approach from others toward alcoholism. It is reflected through direct complaint to the problem of alcoholism, threats of divorce, proposing treatment and, finally, initiating coercive treatment.

I would come home, I don't know what stage of intoxication was, mostly I came home, lay down and fell asleep ... and that it culminated, I do not know what it was, I came bome, saw my wife... and had a band full of pills. ... I asked her "Do you want me to drink. this now?" ... and later son came and told me "Pack your stuff, and we're going." It was a moment when she cried and told me to go (R1).

During treatment, relationships are still ambivalent: on one hand participants sense support from family, friends and employers. However, for some, the treatment was a risk for further development of family relationships: for example, two participants perceive it as a conspiracy of his wife and children, one participant expressed difficulty in achieving communication with her daughter after the compulsory referral to treatment and one sees treatment as further distancing from wider environment.

Participants recognize implications of treatment on improved quality of family relationships: they sense a desire for further work on relationships, spending time with family, maintaining contact with family and improved self-presenting and expressing themselves. On the other side, some of them report on non-supportive social context. The range goes from the lack of support, creation of passive pressure during treatment, environmental stigma of treatment or consider it as unnecessary, till the inducement of drinking.

During the development of abstinence, supportive relationships are recognized within the family that provides support in various forms (assistance with daily activities, dialogue and understanding, companion at the club meetings, expressing trust), friends who do not drink near them and support sobriety, and among members of the club in a way that the older abstainers are a role model, mutual support and understanding by the therapist is provided.

I was attracted to the club by people who were honest. So, I came here for New Year's by walk from my house on snow when there was a big snowstorm. Others wouldn't come. And I came here and found a man who was 25 years sober, and he came. If he who has 25 years of abstinence can come, why wouldn't I with 2 or 3 years? It's a big difference if you find some kind of role model in a club (R7).

However, some participants are faced with aggravating relations: stigmatisation, lack of understanding of alcoholism and constantly reminding on a period of drinking. Thus, some 
relations are becoming more distant, and participants turn to family obligations, renewing contacts with children and the reconstruction of old friendships.

My son has graduated and I went to his promotion. I cried from joy for bim and sadness for daughter's promotion ... I established contact with her later. And with my son I never had a problem, but couldn't get closer. And once he told me: "Let's forget it and move on with life normally". However, that feeling of guilt...Later, when we opened up a little to one another, I knew what he should have as a boy, and danghter also. You have to say it no matter when, as soon as it is said, before it is solved (R2).

Behavioural aspects of experiences

In accordance with the differences in previous dimensions of experiences, two different thematic areas are noticed in behavioural aspects of the development of alcoholism: antisocial behaviours that are manifested in aggressive behaviour or avoidance of contact with others, passive behaviour in achieving life objectives and reducing social contacts and prosocial behaviour as openness to socializing with others, or peaceful behaviour.

I behaved normally when I was drunk and when I wasn't. I'm not aggressive or anything like that. In my 41 years, I never got in fight with anyone. I said if we can drink - ok, if not - I moved. If someone started to provoke, I would charge my account and went home. I am not of such nature. When I saw two arguing, I invited them to drink, and leave it to them (R8).

During treatment, the most dominant theme is achieving coherence of decisions and bebaviours. This means that the decision is followed by consistent behaviour, and all participants emphasized this connection.
In the maintenance of abstinence, three themes occurred: a life without alcohol, detabuisation of alcohol and behavioural changes. Life without alcohol includes alcohol rejection from environment, construction of abstinence on a daily basis, and public confession of alcoholism and treatment. Several participants mention that after certain time it comes to detabuisation of alcohol, which includes its re-introduction into the environment, but without their own consumption.

Speaking of that, it is often said in the club that we shouldn't have alcohol at home. I have it, I have wine, I have a beer, I have brandy. Why not to offer someone who comes as guest? Someone who is a regular consumer or any other person that likes to have a glass of wine after a good lunch. Regarding alcohol, this part of the brain is blocked for me. I pass by the beer at the store, but don't perceive it. ... I had my drink (R1).

On a broader basis, the participants speak about the general behaviour changes reflected in different ways: activation in social events, taking on more responsibilities, or return of former habitual behaviour before the development of alcoholism.

The catch is that abstinence ultimately contributed to my behaviour in society in general. ... And what did I get with it? I got peaceful life, control, living normally on daily basis and everything that goes with it, but also related to the family (R5).

I started to laugh, I began to talk, and I'm happy about that.... I opened up my soul. I think I slowly began to return to where I was before. I have been in contact with people for 18 years, from lowest to bighest class. And so I learned to adapt. I gained the habit of socializing and communicating. I think that I'm slowly returning there (R3). 


\section{Discussion}

In short, answer to our research question on characteristics of experiences of people in alcoholism treatment is that these experiences are non-linear, personal trajectories are different, and above all they are multidimensional.

In stage when alcoholism is developing, attempts of balancing and experiments with sobriety exist, and participants assign different meanings to drinking. It is particularly important to place them in social context with high availability of alcohol. Croatian Society is estimated as society with an average consumption of alcohol and that alcohol is almost ubiquitously consumed among $90 \%$ of men and $81 \%$ women with $15.7 \%$ of consumers in high-risk populations [19]. Women have somewhat different story. Female participants indicated this functional component of alcoholism that is shown in other studies. For example, Agrawal and associates found among the most important motives for women drinking an increase of sociability, calming effect, adjustment to stressful situation, gaining a sense of power, encouragement to deal with the problems and improve self-image. Still, knowledge on women's alcoholism is rudimentary [20].

In stage of crucial change that mostly happens within hospital treatment, treatment itself is generator of many specific challenges with many experiences of emotional, $\operatorname{cog}$ nitive or behavioural crisis during abstinence. People facing alcoholism spend most of their lives on an emotional rollercoaster. Same as in other studies, we have tackled issue of comorbidity of alcoholism and depression [21, 22]. The dominant approach in pharmacotherapy and monitoring patient just shortly after the hospital treatment seems insufficient.
In stage of maintaining abstinence, participants differ in a way that some have narrower approach focusing on abstinence as behavioural task; while other have more holistic approach viewing alcoholism just as an inducement for overall transformation. These broader implications of alcoholism treatment on quality of life in general were found in other researches in a sense that strengthening motivation for higher quality of life acts as a protective factor, and support directed to treatment and maintaining abstinence decreases over time as the focus shifts on quality of life in all levels [23]. In this process, as it is already demonstrated in numerous researches, family surrounding plays crucial role both for developing and resolving alcoholism [24-27].

Experiences related to alcoholism and treatment are multidimensional and more introspective. Phenomenological study enables us to get intimate personal stories that have strong legitimacy [27]. Most of themes appear from personal reasoning on thoughts, emotions, behaviours and relationships with other. Concrete events and biographical facts seem to be less elaborated. In certain aspects ambivalences can be found among and even inside particular life story. This is particularly evident in cognitive, emotional aspects and relations with others. Revealed themes provide overview of various aspects that are important to be integrated in further practical and scientific work on alcoholism as a wider psychosocial phenomenon.

\section{Acknowledgements}

None.

\section{Conflicts of interest}

None to declare. 


\section{References}

1. Zoričić Z. Problemi povezani s pijenjem alkohola u mladih ljudi u Republici Hrvatskoj [Internet]. Croatian Association of Clubs of treated Alcoholics. 2011. [cited 15 October 2018]. Available from:http://www.hskla.hr/OvisnostOalkoholu/ problemiS_pijenjem.htm

2. Croatian National Institute of Public Health. Croatian Health Service Yearbook 2009. Internet]. Croatian National Institute of Public Health. 2010. [cited 15 October 2018] Available from: http://www.hzjz.hr/publikacije/hzs_ljetopis/Ljetopis_Yearbook_HR_2009.pdf

3. World Health Organization. Lexicon of alcohol and drug terms [Internet]. World Health Organization. 1994. [cited 15 October 2018]. Available from: http://whqlibdoc.who.int/publications/9241544686.pdf

4. Miljenović A. Psihosocijalni pristup i alkoholizam: iskustvo rada u klubovima liječenih alkoholičara. Ljetopis socijalnog rada 2010;17:281-94.

5. Bowden JW. Recovery from alcoholism: a spiritual journey. Issues Ment Health Nurs 1998;19:337-52.

6. Rhodes T, Coomber R. Qualitative methods and theory in addiction research. In: Miller PG, Strang J, Miller PM, editors. Addiction Research Methods. Oxford: Blackwell Publishing Ltd.; 2010. p. 59-78.

7. Parks KA, Miller BA, Collins L, Zetes- Zanatta L. Women's Descriptions of Drinking in Bars: Reasons and Risks. Sex Roles 1998;38:701-17.

8. Rudolfsdottir AG, Morgan P. 'Alcohol is my Friend': Young Middle ClassWomen Discuss their Relationship with Alcohol. J Community Appl Soc Psychol 1998;19:492-505.

9. Shinebourne P, Smith JA. Alcohol and the self: An interpretative phenomenological analysis of the experience of addiction and its impact on the sense of self and identity. Addict Res Theory 2009;17:152-67.

10. Ambrogne JA. Managing Depressive Symptoms in the Context of Abstinence: Findings From a Qualitative Study of Women. Perspect Psychiatr Care 2007;43:84-92.

11. Orford J, Dalton S, Hartney E, Ferrins-Brown M, Kerr C, Maslin J. How is excessive drinking maintained? Untreated heavy drinkers' experiences of the personal benefits and drawbacks of their drinking. Addict Res Theory 2002;10:347-72.
12. Ekendahl M. Alcohol abuse, compulsory treatment and successive aftercare: a qualitative study of client perspectives. Int J Soc Welf 2009;18:2609.

13. Wilkinson S, Mistral W, Golding J. What is most and least useful in residential rehabilitation? A qualitative study of service users and professionals. Journal of Substance Use 2008;13:404-14.

14. Mohatt GV, Rasmus SM, Thomas L, Allen J, Hazel $\mathrm{K}$, Marlatt GA. Risk, resilience, and natural recovery: a model of recovery from alcohol abuse for Alaska Natives. Addiction 2008;103:205-15.

15. Yeh MY, Che HL, Wu SM. An ongoing process: a qualitative study of how the alcohol-dependent free themselves of addiction through progressive abstinence. BMC Psychiatry 2009;9:76.

16. Brown CG, Stewart SH. Exploring Perceptions of Alcohol Use as Self Medication for Depression Among Women Receiving Community-Based Treatment for Alcohol Problems. J Prev Interv Community 2008;35:33-47.

17. Smith JA, Osborn M. Interpretative phenomenological analysis. In Smith JA, editor. Qualitative Psychology: A Practical Guide to Research Methods. London: Sage Publicationd Ltd.; 2003. p. 5181.

18. Miles MB, Huberman M. An expanded sourcebook: Qualitative data analysis. London: Sage Publications Inc.; 1994.

19. Government of Republic of Croatia. National Strategy for prevention of alcohol misuse and alcohol related disorders 2011-2016 [Internet]. Government of Republic of Croatia. 2010. [cited 15 October 2018]. Available from: http://www.mzss. $\mathrm{hr} / \mathrm{hr} /$ ministarstvo/strategije_i_planovi/nacionalna_strategija_za_spreca spre_stetne_uporabe_ alkohola_i_alkoholom_uzrokovanih_poremecaja_ za_razdoblje_od 2011_2016_godine

20. Agrawal A, Dick DM, Bucholz KK, Madden PAF, Cooper ML, Sher KJ, et al. Drinking expectancies and motives: a genetic study of young adult women. Addiction 2008;103:194-204.

21. Golik-Gruber V, Breitenfeld D, Gruber EN, Karlović D. Sulpiride psychopharmacotherapy in patients with alcohol addiction and depression comorbidity. Acta Clin Croat 2003;42:29-33.

22. Paljärvil T, Koskenvuo M, Poikolainen $\mathrm{K}$, Kauhanen J, Sillanmäki1 L, Mäkelä P. Binge drink- 
ing and depressive symptoms: a 5-year populationbased cohort study. Addiction 2009;104:1168-78.

23. Laudet AB, Morgan K, White WL. The Role of Social Supports, Spirituality, Religiousness, Life Meaning and Affiliation with 12-Step Fellowships in Quality of Life Satisfaction Among Individuals in Recovery from Alcohol and Drug Problems. Alcohol Treat Q 2006;24:33-73.

24. Copello AG, Velleman RDB, Templeton LJ. Family interventions in the treatment of alcohol and drug problems. Drug Alcohol Rev 2005;24:369-85.

25. Carroll J. Addicts' Family Members Say Lack of Willpower Top Addiction Factor: Ease of obtaining drugs or alcohol and psychological illness also cited as top factors. [Internet] Gallup, UK. 2006. [cited 15 October 2018]. Available from http:// www.gallup.com/poll/24094/addicts-familymembers-say-lack-willpower-top-addiction-factor. aspx

26. van Wormer K. Counseling Family Members of Addicts/Alcoholics: The Stages of Change Model. J Fam Soc Work 2008;11:202-21.

27. Graff FS, Morgan TJ, Epstein EE, McCrady BS, Cook SM, Jensen NK, et al. Engagement and Retention in Outpatient Alcoholism Treatment for Women. Am J Addict 2009;18:277-88.

28. Lopez KA, Willis DG. Descriptive Versus Interpretive Phenomenology: Their Contributions to Nursing Knowledge. Qual Health Res 2004;14:726-35.

\section{Od alkoholizma do čvrste apstinencije: otkrivanje multidimenzionalnih iskustva liječenih alkoholičara u Hrvatskoj}

Sažetak - Alkoholizam je značajan javnozdravstveni problem u Hrvatskoj koji utječe na gotovo četvrtinu populacije. Međutim, u ovom području nedostaje kvalitativnih istraživanja koja bi ukazala na kompleksnost fenomena i iskustva povezana s alkoholizmom, tretmanom i uspostavljanjem apstinencije. Rad se temelji na fenomenološkom kvalitativnom istraživanju sa devet sudionika koji su prošli kroz razvoj ovisnosti sve do uspostavljene apstinencije. Rezultati ukazuju da iskustva sudionika nisu linearna, osobne trajektorije se razlikuju te iznad svega ona su multidimenzionalna. Multidimenzionalna iskustva konstruirana su na sljedećim razinama: kognitivnoj, emocionalnoj, ponašajnoj, aspektu odnosa s društvenim okruženjem, važnim životnim događajima i doživljaju tretmana alkoholizma u užem kliničkom smislu. U fazi razvoja alkoholizma, postoje pokušaji balansiranja i eksperimentiranja s trijeznim razdobljem te sudionici se razlikuju s obzirom na to kakva značenja pripisuju pijenju. U fazi ključne promjene što je najčešće tijekom bolničkog tretmana, sam tretman je generator brojnih specifičnih izazova s doživljajima emocionalnih, kognitivnih i ponašajnih kriza u uspostavljanju apstinencije. U fazi uspostavljanja stabilne apstinencije sudionici se razlikuju na način da se dio njih posvećuje apstinenciji u užem smislu fokusirajući se na apstinenciju kao ponašajni zadatak; dok drugi dio zastupa holistički pristup promatrajući alkoholizam kao poticaj cjelokupne transformacije. Iskustva povezana s alkoholizmom i tretmanom su višedimenzionalna i introspektivna. Fenomenološka studija omogućuje uvid u osobne životne priče koje imaju snažni legitimitet u daljnjoj praksi i istraživanjima u ovom području.

Ključne riječi: alkoholizam, fenomenološka analiza, kvalitativna studija 